\title{
MEDIA SOSIAL DAN KEBERAGAMAN ILMU DAKWAH SEBAGAI AKTIVITAS SOSIAL DI MASA PANDEMI
}

\author{
NURHALISA \\ Institut Agama Islam Negeri (IAIN) Parepare, Fakultas Ushuluddin Adab \& Dakwah, \\ Program Studi Komunikasi \& Penyiaran Islam \\ e-mail : nurhalisa002@iainpare.ac.id
}

\begin{abstract}
Abstrak
Perkembangan teknologi sangat pesat, dengan adanya media sosial semakin pintar pula masyarakat dalam mengakses media sosial. Dalam dakwah sekarang media sosial sangat dibutuhkan, karena dimasa pandemi sekarang tidak boleh mengumpulkan massa jadi melalui media sosial semua orang bisa berdakwah secara tatap muka tetapi tidak bertemu secara langsung. Perkembangan dakwah dari berbagai seri memberi keharusan agar dapat melihat berbagai macam metode yang dapat memudahkan penyebaran informasi dakwah. Bukan hanya hal positif yang ada didalamnya, tetapi hal negatif juga marak ada didalam media sosial seperti penyebaran berita hoax atau bohong, maraknya foto atau video yang tidak senonoh dan masih banyak lagi. Media sosial membuat orang semakin lupa akan aktivitasnya. Dalam masyarakat sekarang media sosial menjadi kegiatan sehari-hari, karena sudah tidak adanya pekerjaan yang mereka kerjakan akibat adanya pandemi ini. Dengan adanya media sosial mereka sangat mudah mengaksesnya, baik dari kalangan orang dewasa sampai anal-anak menggunakannya. Karena pendidikan sekarang telah dilakukan secara daring dari anak SD sampai mahasiswa. Dakwah di media sosial sangat memberi potensi agar lebih tau bagaimana dakwah yang sebenarnya sebagai penganut ajaran Islam.
\end{abstract}

Kata Kunci : Media sosial, ilmu dakwah, aktivitas sosial, pandemi. 


\section{PENDAHULUAN}

Dakwah ke depan menempatkan perencanaan dan strategi yang tepat dengan merujuk kepada metode dakwah Rasulullah SAW. Para intelektual muslim dapat merumuskan konsep dan metode dakwah untuk generasi muda, orang dewasa atau objek dakwah bagi berbagai lapisan masyarakat yang tingkat pemahaman keagamaannya tergolong rendah atau sebaliknya bagi masyarakat yang tingkat pendidikannya tergolong tinggi, sehingga materi dakwah sesuai dengan objeknya.

Problematika dalam dakwah merupakan salah satu persoalan ummat Islam yang perlu mendapat perhatian serius dari kita semua sebab persoalan dakwah merupakan persoalan masa depan umat Islam. Hal ini bisa kita lihat dalam catatan sejarah bahwa perkembangan agama Islam ke seluruh penjuru dunia adalah dibawa dan disampaikan oleh para juru dakwah sesuai dengan kondisi dan situasi saat itu.

Penyampaian dakwah pada masa dahulu tentu akan sangat berbeda dengan pada masa sekarang ini, sebab kondisi dan situasi yang dihadapi pada masa lalu berbeda dengan situasi yang dihadapi pada masa kini, permasalahan dakwah pada saat ini lebih komplek dibandingkan pada masa itu. Untuk itu perlu dilakukan semacam evaluasi kritis dan mendasar terhadap penyampaian dakwah meliputi, metode, media dan materi dakwah dengan harapan dapat mengatasi persoalan-persoalan yang dihadapi ummat islam.

Sebagai aktivitas sosial-keagamaan, dimasa pandemi sekarang semua orang akan membutuhkan yang namanya teknologi informasi maupun komunikasi. Jadi sekarang semua orang beralih ke media soial untuk mengakses segala informasi yang ada didalamnya tersebut. Pada dasarnya dakwah telah merambah kemana-mana dan kita sebagai umat muslim harus tau tentang itu dan mengamalkannya. Di masa pandemi ini kita manfaatkan sebagai peluang untuk mendapatkan lebih banyak ilmu melalui dakwah di media sosial. 
Perkembangan teknologi yang ada semua memanfaatkan akibat adanya pandemi ini, karena semuanya terkontrol dari rumah jadi orang-orang akan bosan ketika tidak ada yang mereka kerjakan dirumah. Jadi dakwah dijadikan sebagai aktivitas sosial dimasa pandemi ini seperti berdakah bersama keluarga yang sebelumnya ke mesjid untuk mendengarkan ceramah, hal ini akan semakin memperat keutuhan keluarga dan memperdalam ilmu dakwah yang dimiliki. Dakwah sebagai pesan yang disampaikan kepada khalayak dengan tujuan yang menuju kebaikan. Dakwah juga pada hakikatnya adalah proses peningkatan iman dalam diri manusia sesuai syariat islam. Hal ini menunjukkan adanya sebuah kegiatan yang dilakukan secara terus menerus, berkesinambungan dan bertahap serta peningkatan perubahan yang positif, dari kondisi buruk menjadi baik atau dari yang sudah baik menjadi lebih baik lagi. 
PEMBAHASAN

\section{Media Sosial}

Perkembangan dakwah dari berbagai seri memberi keharusan agar dapat melihat berbagai macam metode yang dapat memudahkan penyebaran informasi dakwah. Dengan adanya internet, jangkauan teknologi informasi menjadi lebih luas, tidak mengenal batas ruang dan waktu.

Tidak dipungkiri bahwa dengan adanya akses internet bukan hanya hal positif yang terkandung didalamnya melainkan ada juga hal negatif, jadi kembali pada diri kita bahwa harus pandai-pandai mengakses internet karena dakwah sebagai akses penyebaran nilai dakwah, hal tersebut akan dinilai sebagai sesuatu yang sudah usang baik dari sisi metode yang digunakan maupun subjeknya. Sebagai nilai dakwah kita harus mencari atau mengakses internet dyang didalamnya terkandung hak positif dan hal yang tidak mengandung unsur kebohongan atau hoax. Disinilah kita memanfaatkan dakwah sebaik-baiknya sebagai aspek penyebaran 
informasi yang akurat. Pesatnya perkemnbangan dunia maya mengacu berbagai kalangan untuk menuangkan gagasannya mulai dari web personal sampai dengan web yang memang diperuntukan bagi masyarakat umum sebagai fasilitator berdakwah. Dengan demikian, jika sekarang kita mencoba melakukan pencarian dengan kata "muslim" sebagai kata kuncinya, tentu ribuan bahkan ratusan ribu situs menyediakan informasi terkait dengan "muslim". Setiap tahunnya pengguna internet meningkat, hal ini tentu menjadi momentum untuk menyebarkan sekaligus menanamkan nilai-nilai Islam pada masyarakat. Media yang menyediakan informasi tersebut tidak hanya berbentuk web, melainkan dengan milis pun diskusi forum akan dapat dijalankan. Hal ini dianggap sangat efisien dan efektif karena dapat dengan cepat menyampaikan informasi.

Demikian dengan adanya pandemi Covid-19 sekarang yang menyerang dunia, peran internet sangat meningkat karena adanya peraturan pemerintah yang mengharuskan kita belajar dan kerja dirumah, itu semua akan mengakses inernet karena dilakukan secara online. Jadi mau tidak mau penggunaan internet dilakukan terus menerus selama adanya pandemi ini, banyak juga sisi positif dan negaifnya. Para orang tua siswa mengeluh, karena tidak semua wilayah bisa mengakses internet tersebut karena tidak mendukungnya jaringan internet. Dengan pandemi ini, ekonomi, sosial, dan pendidikan sangat buruk, apalagi karyawan perusahaan sebagian di PHK, ini untuk mengurangi penyebaran virus Covid -19 .

Media sosial sangat berkembang pesat saat ini, terutama di masa pandemi ini media sosial sangat dibutuhkan karena informasi yang terus masyarakat tunggu dengan perkembangan pandemi ini. Kebutuhan dalam mengakses media sosial sangat meningkat, disinilah kita dapat memanfaatkannya sebagai kebutuhan dakwah untuk mencari dan berbagi ilmu sesama manusia, selain mendapat ilmu kita juga dapat pahala dan wawasan lebih luas mengenai dakwah yang ada di sekitar kita. Tetapi dalam mengakses media sosial, kita harus bisa membedakan mana yang 
mengandung unsur negatif maupun positif, karena pada zaman sekarang teknologi semakin canggih orang-orang pun semakin pintar menyediakan informasi yang bersifat bohong atau hoa yang tidak dipertanggungjawabkan.

Jadi, di masa pandemi ini, dalam menyampaikan dakwah tidak mesti dengan mengumpulkan massa untuk orang dengarkan dakwah kita, tetapi bisa melalui media sosial, baik secara tertulis maupun bertatapan langsung meski tidak bertemu, karena demi mencegah penularan Covid-19. Adanya media sosial orang-orang berubah dengan aktivitasnya, misalnya sebelum menggunakan media sosial mereka selalu rajin, tetapi setelah adanya media sosial merekapun bermalas-malasan. Media sosial tidak selamanya bisa bergantung terus menerus, selain itu kita punya aktivitas lain yang lebih berguna dan orang lain pun bisa merasakan manfaatnya apabila kita melakukan apa yang mereka harapkan.

\section{Keberagaman ilmu dakwah}

Bangsa indonesia sendiri adalah bangsa yang sering disebut sebagai bangsa paling majemuk di dunia. Di negara dengan jumalh penduduk lebih dari 200 juta jiwa ini, berdiam tidak kurang dari 300 etnis dengan identitas kulturnya masing-masing. Berbagai macam agama, suku, budaya, adat istiadat, serta golongan. Demikian dengan keragaman yang berbeda dengan negara lain tidak membuat Islam memilih-milih, semuanya sama dimata islam baik itu perbedaan agama ataupun bahasa. Kita senantiasa harus menerima perbedaan itu dan tidak melecehkan satu sama lain, bukan hanya itu kita harus juga ,menghormati sesama manusia. Demikian juga sebuah hadist yang sering kita dengar secara eksplisit menyerukan agar kita menyampaikan kebenaran dari Nabi meskipun satu ayat serta beberapa dalail lain yang kompaitable dengan anjuran dakwah. Satu hal yang mesti digaris bawahi adalah bahwa dakwah hendaknya dilakukan secara bijaksana dan penih kedewasaan. Kedewasaan sebagai umat yang akan mengantarkan keluhuran Islam dimata kelompok lain 
serta menjadikan orang lain merasa aman dan tak terancam dengan Islam.

Keragaman audiens sasaran dakwah menuntut metode dan materi serta strategi dakwah yang beragam pula sesuai kebutuhan mereka. Nabi sendiri melalui hadisnya menganjurkan pada kita untuk memberi nasehat, informasi kepada orang lain sesuai tingkat kemampuan. Dakwah hendaknya dilakukan dengan menafikkan unsur-unsur kebencian. Esensi dakwah mestilah melibatkan dialog bermakna yang penuh kebijaksanaan, perhatian, kesabaran dan kasih sayang. Dakwah juga dilakukan secara persuasif, jauh dari sikap memaksa, karena sikap yang demikian disamping kurang sopan juga akan berakibat pada penolakan orang mengikuti seruan sang pendakwah yang akhirnya akan membuat misi suci dakwah menjadi gagal. Demikian juga kita harus menghindari pikiran dan sikap menghina dan menjelek-jelekkan agama atau menghujat Tuhan yang menjadi keyakinan umat agama Islam.

1. Landasan ilmu dakwah

sebagai ilmu adalah mengajak kearah kebaikan dengan tujuan yang baik pula. Dakwah dikaji sebagai disiplin ilmu yang mandiri dan sebagai bagian dari bidang ilmu islam. Keragaman ilmu dakwah membahas tentang proses penyampaian, pengelolahan dan penerimaan ajaran islam untuk mengubah perilaku individu, kelompok dan audiens atau masyarakat sesuai dengan ajaran islam, dan itu tidak lagi menyampaikan secara pribadi tetapi mengarah kepada semua orang.

2. Sumber dakwah Islam

Al-Qur'an, adalah pedoman hidup yang pertama bagi umat Islam. Al-qur'an adalah kitab dan sumber inspirasi sebagai rujukan dakwah. Dakwah sebagai kebutuhan umat manusia terhadap hidayah Allah yang menentukan keyakinan manusia kepada Allah serta senantiasa membimbing keimanan dan menuntun akal dalam mencari atau menjalankan kebenaran.

3. Konteks atau bentuk dakwah 
- Tabligh Islam secara bahasa artinya "menyampaikan". Tabligh adalah menyampaikan sesuatu tentang islam kepada orang lain atau khalayak.

- Irsyad Islam secara bahasa artinya "bimbingan", sedangkan secara istilah adalah "mengatakan". Proses penyampaian dan internalisasi ajaran Islam melalui kegiatan bimbingan, penyuluhan dan psikoterapi Islam dan sasarannya individu atau kelompok kecil.

- Tadbir Islam secara istilah artinya kegiatan dakwah dengan perpindahan ajaran Islam melalui kegiatan aksi amal saleh berupa penataan lembaga dakwah dan kelembagaan Islam.

- Tathwir Islam secara bahasa artinya "pengembangan" sedangkan secara istilah artinya kegiatan dakwah dengan implementasi ajaran Islam melalui pemberdayaan sumber daya manusia dan sumber daya lingkungan dan ekonomi umat dan pengembangan muslim.

Dari hasil wawancara pada salah satu mahasiswi Universitas Negeri Muslim terkait media sosial dan keberagaman ilmu dakwah sebagai aktivitas sosial dimasa pandemi. Menurutnya media sosial adalah kegiatan ilmu dakah sebagai aktivitas sosial untuk saat ini penting apalagi sekarang kita hidup di zaman modern dan tidak dapat dipisahkan dari handphone atau telepon genggam. Apalagi dimasa PSBB (pembatasan sosial berskala besar). Orang-orang mulai meninggalkan tv dan beralih ke handphone sebagai sumber informasi, inspirasi, sarana hiburan, sarana dalam beraktivitas (bekerja) didalam rumah. Media sosial sebagai sarana berdakwah dimasa pandemi ini juga dianggap paling efektif karena tidak mengurangi asensi dan prinsip dalam berdakwah. Melalui media sosial, pendakwah berhasil menyebarkan pesan-pesan positif dan mendorong lahirnya gerakan dakwah secara cepat dan luas. Namun, banyak hal yang harus diperhatikan, harus mengutamakan sikap moderat 
dalam beragama dan isi dakwahnya harus dapat dipertanggungjawabkan. ${ }^{1}$

\footnotetext{
${ }^{1}$ Amelia, Nurul (Mahasiswi Universitas Negeri Muslim Makassar), Wawancara oleh Nurhalisa. Via Media Sosial. 22 Juli 2020
} 


\section{PENUTUP}

\section{KESIMPULAN}

Media sosial merupakan sebuah media daring dengan cara penggunaannya bisa dengan mudah berpartisipasi, berbagi dan menciptakan jejaring sosial yang merupakan bentuk media sosial yang paling umum digunakan masyarakat diseluruh dunia. Media sosial kini sangat berkembang pesat, karena dimasa sekarang teknologi semakin canggih. Untuk itu sangat bermanfaat bagi kita dalam mencari informasi yang kita inginkan. Tetapi ada juga sisi negatifnya, itu sangat mengubah aktivitas kita untuk semakin berlarut-larut menggunakan media sosial.

Dakwah adalah menyeru atau mengajak kearah kebaikan dan dengan tujuan yang baik pula. Dakwah dimasa pandemi ini menjadi aktivitas sosial, karena untuk mencegah penularan Covid-19 dalam berdakwah tidak boleh sementara mengajak massa dalam dakwah kita. Dengan adanya media sosial dapat dilakukan secara online meskipun tidak bertatapan dengan langsung tetapi melalui telepon genggam. Demikian dapat pahala dan juga menambah ilmu meski tidak secara langsung.

Keragaman audiens sasaran dakwah menuntut metode dan materi serta strategi dakwah yang beragam pula sesuai kebutuhan mereka. Nabi sendiri melalui hadisnya menganjurkan pada kita untuk memberi nasehat, informasi kepada orang lain sesuai tingkat kemampuan. Dakwah hendaknya dilakukan dengan menafikkan unsur-unsur kebencian. Esensi dakwah mestilah melibatkan dialog bermakna yang penuh kebijaksanaan, perhatian, kesabaran dan kasih sayang. Dengan adanya keragaman di Bangsa Indonesia, tidak menuntut kita untuk mebeda-bedakan sesama muslim karena perbedaan menjadikan negara kita akan lebih maju dan tidak menimbulkan kesalahpahaman antar sesama budaya, agama, suku, ras dan golongan. Semuanya sama dimata Tuhan, perbedaan warna kulit tidak menghalangi kita untuk mencintai sesama bangsa Indonesia. Perbedaan itu sangat relevan sehingga kita harus menghormati satu sama lain tanpa membeda-bedakannya. 


\section{DAFTAR PUSTAKA}

Maryatin. Efektivitas Metode Ceramah Dalam Penyampaian Dakwah Islam. Volume 34, Nomor 1. Januari - Juni 2014

Jatnika Wawan Asep, Yedi Purwanto, Muhamad Taufik. Peran Teknologi Informasi Dalam Perkembangan Dakwah Mahasiswa. Volume 16, Nomor 1. April 2017

Islam Arifin Muhammad, Muchammad Bayu Tejo Sampurno, Tri Cahyo Kusumandyoko. Budaya Media Sosial, Edukasi dan Pandemi Covid-19. Volume 7, Nomor 6. 2020 